\title{
NGHIÊN CỨU VÀ ĐỀ XUẤT BIÊN PHÁP GIẢM THIỂU Ô NHIỄM MÔI TRƯỜNG NƯỚC DO HOATT ĐộNG CHĂN NUÔI TẠI THÀNH PHỐ PLEIKU TỈNH GIA LAI
}

\author{
HUỲNH NGỌC ANH, NGUYẼ̃N THỊ THÁI HÀ, NGUYẼ̃N THỊ HOÀNG ĐIỆP \\ Phân hiệu Đại học Nông Lâm Thành phố Hồ Chí Minh tại Gia Lai \\ huynhngocanhgl@gmail.com,nguyenthaiha0610@gmail.com,hoangdiep2109@gmail.com
}

\begin{abstract}
Tóm tắt. Chăn nuôi ngày càng phát triển, mang lại nguồn lợi về kinh tế cho nhiều hộ chăn nuôi. Bên cạnh đó, hoạt động chăn nuôi cũng gây ra ô nhiễm môi trường xung quanh. Do đó, đề tài được thực hiện nhằm đánh giá thực trạng môi trường chăn nuôi trên địa bàn Thành phố Pleiku, xác định mức độ ô nhiễm của chất thải chăn nuôi đến môi trường nước mặt và nước ngầm và đề xuất giải pháp quản lý, xử lý chất thải chăn nuôi, giảm thiểu tác động đến môi trường. Đề tài được thực hiện thông qua việc lấy mẫu nước, phân tích để xác định mức độ ô nhiễm do chất thải chăn nuôi; Khảo sát thực địa, lấy ý kiến của hộ chăn nuôi và cán bộ quản lý để nắm được hiện trạng chăn nuôi và công tác quản lý của cán bộ địa phương. Sử dụng phương pháp thu thập, phân tích, tổng hợp số liệu, tài liệu, điều tra xã hội học. Kết quả đề tài đã đạt được: Xác định được hiện trạng môi trường chăn nuôi tại Tp.Pleiku; Đánh giá mức độ ô nhiễm môi trường nước do chất thải chăn nuôi tại Tp.Pleiku; Đưa ra một số giải pháp phù hợp với tình hình địa phương trong việc xử lý nước thải chăn nuôi.
\end{abstract}

Từ khóa. Biện pháp giảm thiểu ô nhiễm, chất thải chăn nuôi, thực trạng môi trường.

\section{RESEARCH AND PROPOSE MEASURES TO REDUCE ENVIRONMENTAL POLLUTION OF LIVESTOCK WATER IN PLEIKU CITY, GIA LAI PROVINCE}

\begin{abstract}
Livestock is growing, bringing economic benefits to many livestock producers. Besides, Livestock activities also cause environmental pollution. So, The topic was carried out to evaluate the situation of animal husbandry environment in Pleiku city, to determine the level of contamination of animal wastes to the surface water and groundwater environment and propose management solutions, animal waste treatment, minimizing the impact on the environment. Topics were taken through water sampling, analysis to determine the level of pollution caused by livestock waste; Field surveys, consultation with livestock producers and managers to understand the current status of livestock production and the management of local staff. Using methods of collecting, analyzing, synthesizing data, documents and sociological surveys. The results are: Determine the current livestock environment in Pleiku City; Assess the level of environmental pollution caused by animal waste in Pleiku City; Give some solutions suit the local situation in the livestock wastewater treatment.
\end{abstract}

Keywords. Measures to reduce pollution, livestock waste, environmental status.

\section{1 ĐẶT VẤN ĐỀ}

Ngành chăn nuôi là ngành phát triển khá bền vững và đã đạt được những kết quả đáng ghi nhận trong những năm gần đây. Việc phát triển chăn nuôi giúp cung cấp một lượng lớn thực phẩm cho con người, tạo công ăn việc làm, tăng thu nhập và cải thiện đời sống cho người dân lao động. Vấn đề tồn tại lớn nhất của chăn nuôi là tình trạng ô nhiếm môi trường. Chất thải chăn nuôi thải ra gây ô nhiễm môi trường đất, nước, không khí gây tác động đến sức khỏe của cộng đồng và ảnh hưởng trực tiếp đến việc phát triển bền vững của ngành chăn nuôi.

Thành phố Pleiku là một địa phương có ngành chăn nuôi phát triển khá mạnh. Trong thời gian qua, một số trang trại và hộ chăn nuôi cá thể không đảm bảo điều kiện chăn nuôi gây ô nhiễm môi trường, ảnh hưởng chất lượng cuộc sống khu dân cư, tình trạng chất thải trong chăn nuôi hầu như không được xử lý ở các hộ chăn nuôi nhỏ lẻ tự phát nên công nghệ và kỹ thuật chăn nuôi còn mang tính chắp vá, không đồng bộ, chưa giải quyết vấn đề môi trường một cách căn bản, chưa đảm bảo vệ sinh thú $\mathrm{y}$ theo quy định của 
pháp lệnh thú y nên chất thải thải ra ao, hồ, mương nước, đất gây ô nhiễm môi trường đất, nước, không khí. Với đặc điểm địa hình đồi núi, dân cư đông và sinh sống phân tán, chuồng trại chăn nuôi nằm xen kẽ với nhà ở, cạnh nguồn nước, cho nên việc kiểm soát ô nhiễm môi trường trong chăn nuôi là rất khó.

Đứng trước thực trạng môi trường đang bị suy thoái nghiêm trọng, đề tài "Nghiên cứu và đề xuất biện pháp giảm thiểu ô nhiê̂m môi trường nước do hoạt động chăn nuôi tại Thành phố Pleiku tỉnh Gia Lai" được thực hiện nhằm đưa ra giải pháp cũng như phương hướng quản lý môi trường phù hợp, mang ý nghĩa hết sức thiết thực nhằm cải thiện điều kiện môi trường sống, khẳc phục hiện trạng ô nhiễm để góp phần vào sự nghiệp phát triển bền vững.

\section{PHƯƠNG PHÁP NGHIÊN CÚU}

Đối tượng nghiên cứu: hiện trạng quy mô chăn nuôi và môi trường nước. Phương pháp nghiên cứu:

\section{- Phưong pháp điều tra, thu thập số liệu:}

Tiến hành thu thập tài liệu, số liệu từ các báo cáo, văn bản của phòng tài nguyên môi trường Thành phố Pleiku, phòng nông nghiệp và phát triển nông thôn Thành phố Pleiku, Trạm thú y Tp.Pleiku nhằm tìm hiểu về hiện trạng chăn nuôi và số lượng gia súc, gia cầm . Những kết quả đạt được, những thuận lợi và khó khăn trong quá trình thực hiện công tác quản lý môi trường chăn nuôi trên địa bàn nghiên cứu.

- Phuơng pháp điè̀u tra xã hội họ:

Việc điều tra bằng phương pháp điều tra xã hội học nhằm thu thập số liệu thực tế về hiện trạng kinh tế, môi trường tại khu vực nghiên cứu như: Quy mô, thời gian, mục đích chăn nuôi; Khoảng cách từ chuồng nuôi đến nhà ở và hố chứa chất thải đến giếng; Hiện trạng về quản lý chất thải chăn nuôi, xử lý nước thải tại các hộ chăn nuôi...

Cơ sở của cách xác định mẫu điều tra được tính toán dựa theo số hộ chăn nuôi trên địa bàn 3 phường nghiên cứu, với sai số cho phép $10 \%$. Khu vực điều tra có số hộ chăn nuôi là 898 hộ $(\mathrm{N})$, với sai số cho phép e là 10\%. Áp dụng công thức tính cỡ mẫu Yamena (1968 - 1986 ) điều tra có số lượng điều tra đối với hộ gia đình là

Do đó, số phiếu điều tra là 90 phiếu

$$
\mathrm{n}=\frac{\mathrm{N}}{1+N X(e) 2}=\frac{898}{1+898 X(0,1) 2}=89,98 .
$$

Cách thức tiến hành:

+ Trực tiếp đi xuống địa bàn phường đã chọn nghiên cứu trên địa bàn thành phố, nắm bắt hiện trạng chung của khu vực.

+ Mỗi phường nghiên cứu, chọn các hộ một cách ngẫu nhiên theo danh sách hộ chăn nuôi thu thập từ Trạm Thú Y Thành phố để điều tra.

+ Tiến hành phát phiếu, hỏi trực tiếp và điền các thông tin trên mẫu phiếu điều tra soạn sẵn với số lượng hộ điều tra là: 24-38 hộ/phường.

- Phưong pháp thống kê, so sánh:

Phân tích dữ liệu đã thu thập được từ việc thu thập các báo cáo, văn bản, ... và các thông tin từ điều tra xã hội học, ... Thống kê các tài liệu, số liệu, tổng hợp tạo các bảng, biểu đồ với sự trợ giúp của phần mềm Excel như các bảng biểu về tình hình chăn nuôi và quản lý chất thải chăn nuôi tại Tp.Pleiku, quy mô, thời gian chăn nuôi, phương thức vệ sinh chuồng nuôi, hiện trạng xử lý nước thải của các hộ chăn nuôi được khảo sát... Sau khi thực hiện việc thu thập, nghiên cứu tài liệu thì tiếp tục tiến hành phân tích để đưa ra các đánh giá về nội dung nghiên cứu. Việc nghiên cứu được thực hiện trình tự theo các nội dung để đảm bảo tính hệ thống, tính logic của vấn đề nghiên cứu.

- Phưong pháp khảo sát, phân tích mẫu:

Chọn 3 địa điểm để nghiên cứu: phường Iakring, phường Yên Đỗ; phường Hoa Lư.

* Thời gian lấy mẫu: 2 đợt ( đợt mùa nắng 21/03/2017 và đợt mùa mưa 17/07/2017)

* Vị trí lấy mẫu: 
Mẫu nước mặt: Được lấy mẫu ở quy mô chăn nuôi chiếm tỷ lệ cao nhất (10-50 con).

- M1 (1548054; 826288): Nước mặt tại mương gần hộ chăn nuôi heo hộ bà Phạm Thị Kim Anh. Địa chỉ: 62 Bùi Dự, phường Hoa Lư, Thành phố Pleiku.

- M2 (1547490;822585): Nước mặt tại mương gần hộ chăn heo của ông Võ Văn Đời. Địa chỉ: 442/2 Phan Đình Phùng, phường Yên Đỗ, Thành phố Pleiku.

- M3 (1546642; 823639): Nước mặt tại mương nước gần hộ chăn nuôi heo của bà Trần Thị Mười. Địa chỉ: 10 Tân Tiến, phường Iakring, Thành phố Pleiku.

- Các chỉ tiêu phân tích: pH, TSS, COD, $\mathrm{BOD}_{5}, \mathrm{NO}_{3^{-}}, \mathrm{PO}_{4}{ }^{3-}$, Coliform.

Mẫu nước ngầm nông: Tại giếng đào của các hộ dân nằm trong khu vực chăn nuôi.

- Chỉ tiêu phân tích: pH, COD, $\mathrm{NO}_{3}^{-}$, E. Coli.

- N1(1548050;826177): Nước ngầm tại hộ bà Trịnh Thị Phượng. Địa chỉ: 39 Hoàng Văn Thái, phường Hoa Lư, Thành phố Pleiku.

- N2(1546719;823629): Nước ngầm tại hộ bà Nguyễn Thị Đào. Địa chỉ: 35 Wừu, phường Iakring, Thành phố Pleiku.

- N3 (1547588;822518): Nước ngầm tại hộ ông Hoàng Như Nhân . Địa chỉ: 196 Nguyễn Thiếp, phường Yên Đỗ, Thành phố Pleiku.

\section{Mẫu nước thải}

Lấy theo 2 phương thức thu gom chất thải

- 1 mẫu theo phương thức rửa chuồng trước, hốt phân sau và 1 mẫu theo phương thức hốt phân trước, rửa chuồng sau)

- Số lượng mẫu: 2 mẫu/lần

- Chỉ tiêu phân tích: pH, Tổng N, COD, BOD 5 , TSS, Coliform.

- NT1 (1547490; 822585): Nước thải tại hộ chăn heo của ông Võ Văn Đời. Địa chỉ: 442/2 Phan Đình Phùng, phường Yên Đố, Thành phố Pleiku. Hộ chăn nuôi theo phương thức thức rửa chuồng + hốt phân.

- NT2 (1546642; 823639): Nước thải tại hộ chăn nuôi heo của bà Trần Thị Mười. Địa chỉ: 10 Tân Tiến, phường Iakring, Thành phố Pleiku. Hộ chăn nuôi hốt phân trước rửa chuồng sau.

- Phuơng pháp chuyên gia

Tham khảo ý kiến chuyên gia làm việc trên địa bàn TP.Pleiku trong lĩnh vực chăn nuôi và môi trường như các cán bộ tại UBND phường Iakring, phường Hoa Lư, phường Yên Đỗ, cán bộ Trạm Thú y Tp.Pleiku, cán bộ phòng Tài nguyên - Môi trường Tp.Pleiku để tham vấn thông tin về thực trạng hệ thống chăn nuôi và môi trường như: Đánh giá về tình hình phát thải chất thải chăn nuôi và công tác quản lý của các cơ quan chức năng về chất thải chăn nuôi hiện nay tại Thành phố Pleiku.

\section{KẾT QUẢ VÀ THẢO LUẬn}

\subsection{Khảo sát tình hình chăn nuôi và quản lý chất thải chăn nuôi tại Tp.Pleiku}

\subsubsection{Tình hình chăn nuôi}

Kết quả tổng hợp từ các Báo cáo của Chi cục Thống kê Tp.Pleiku năm 2012 -quý 1/2017 đã thống kê được tình hình phát triển chăn nuôi gia súc, gia cầm thể hiện theo Bảng 1 :

Bảng 1. Tình hình phát triển chăn nuôi gia súc, gia cầm tại Tp.Pleiku

\begin{tabular}{cllcccccc}
\hline \multirow{2}{*}{ STT } & \multirow{2}{*}{ Hạng mục } & \multirow{2}{*}{ ĐVT } & \multicolumn{7}{c}{ Hiện trạng } \\
\cline { 5 - 9 } & & & $\mathbf{2 0 1 2}$ & $\mathbf{2 0 1 3}$ & $\mathbf{2 0 1 4}$ & $\mathbf{2 0 1 5}$ & $\mathbf{2 0 1 6}$ & $\mathbf{2 0 1 7}$ \\
\hline L & Loại & Con & & & & & \\
\hline 1 & Bò & Con & 14.438 & 13.804 & 14.015 & 14.261 & 15.170 & 15.022 \\
\hline 2 & Heo & Con & 72.479 & 58.751 & 71.980 & 72.883 & 71.724 & 70.035 \\
\hline 3 & Gia cầm & Con & 189.630 & 266.013 & 566.779 & 578.284 & 129.160 & 508.853 \\
\hline
\end{tabular}

(Nguồn: Chi Cục Thống kê tỉnh Gia Lai, 2017) [1] 
Số lượng gia súc, gia cầm năm 2017 số lượng bò tăng lên 584 con, heo giảm 2.444 con, gia cầm tăng 319.223 con so với năm 2012. Theo thống kê về số lượng gia súc, gia cầm ở loại hình chăn nuôi hộ gia đình, cho thấy loại hình chăn nuôi này đóng vai trò quan trọng trong việc cung cấp thực phẩm cho Thành phố và toàn tỉnh Gia Lai. Ngoài việc cung cấp thực phẩm cho đời sống con người, chăn nuôi hộ gia đình cũng góp phần cải thiện kinh tế người dân.

Số lượng chất thải chăn nuôi phụ thuộc số đàn gia súc, gia cầm. Theo thống kê của Cục chăn nuôi năm 2015, chất thải chăn nuôi thải ra chủ yếu là phân gia súc, gia cầm. Số lượng chất thải rắn bình quân của bò là $10 \mathrm{~kg} / \mathrm{ngày} / \mathrm{con}$, heo $2 \mathrm{~kg} / \mathrm{ngày} / \mathrm{con}$ và gia cầm là $0,2 \mathrm{~kg} / \mathrm{ngày} / \mathrm{con}$. Do đó, tổng lượng phân thải ra hàng ngày trong năm 2017 tại Tp.Pleiku là 392,061 (tấn/ngày) và 143.102 (tấn/năm). Sản phâm chăn nuôi lớn đồng nghĩa với việc ngành chăn nuôi Thành phố phát triển liên tục. Sự phát triển chăn nuôi cũng làm góp phần phát triển kinh tế và đặc biệt là tăng thu nhập cho người chăn nuôi. Tuy nhiên, mặt trái của sự phát triển này là sự ô nhiễm môi trường trong đó có sự góp phần của chất thải động vật. Với lượng chất thải phát sinh lên đến hàng trăm tấn mỗi ngày như vậy nếu không có biện pháp xử lý thích hợp sẽ để lại hậu quả khó lường cho con người và môi trường.

\subsubsection{Sự phân bố đàn gia súc, gia cầm}

Theo số liệu thống kê của phòng Nông nghiệp và phát triển nông thôn Thành phố Pleiku, năm 2016 số hộ gia đình chăn nuôi heo chiếm $58,13 \%$, số hộ chăn nuôi trâu bò chiếm $11,36 \%$, số hộ chăn nuôi gia cầm chiếm $30,51 \%$.

Bảng 2. Tỷ lệ số hộ gia đình chăn nuôi loại vật nuôi

\begin{tabular}{clcc}
\hline STT & \multicolumn{1}{c}{ Loại vật nuôi } & Số hộ & Tỷ lệ (\%) \\
\hline 1 & Trâu, bò & 102 & 11,36 \\
\hline 2 & Heo & 522 & 58,13 \\
\hline 3 & Gia cầm & 274 & 30,51 \\
\hline & Tổng cộng & 898 & 100 \\
\hline
\end{tabular}

(Nguồn: Phòng nông nghiệp và phát triển nông thôn Thành phố Pleiku, 2016)[5]

Như vậy, trong ngành chăn nuôi thì chăn nuôi heo chiếm tỷ lệ cao nhất, các hộ chăn nuôi tập trung vào chăn nuôi heo, vì đây là loại gia súc dễ nuôi, có thể tận dụng được lượng thức ăn thừa từ nhà bếp.

Kết quả khảo sát 90 hộ chăn nuôi thu được kết quả về:

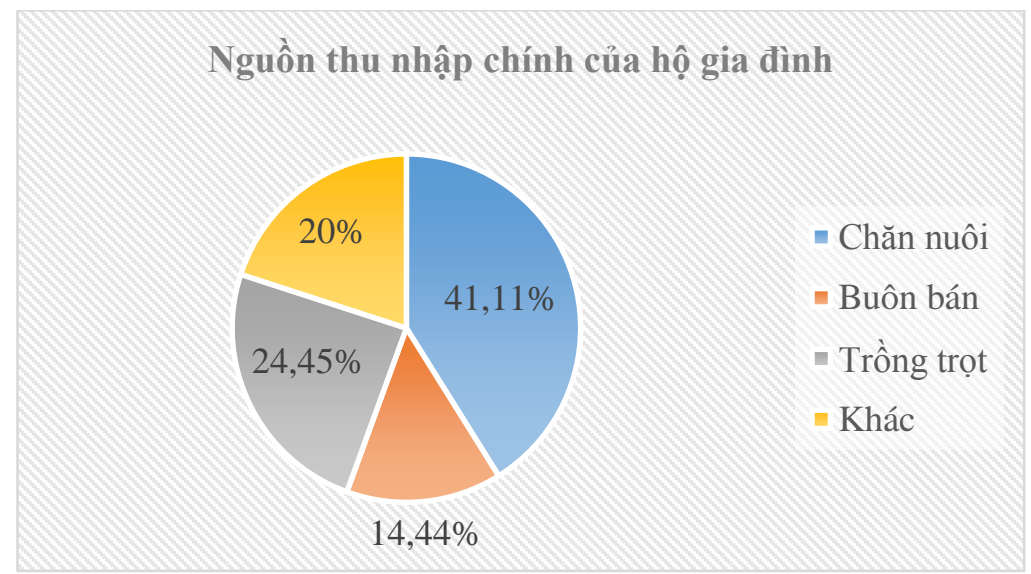

Hình 1. Biểu đồ nguồn thu nhập chính của các hộ gia đình

Nguồn thu nhập chính của một số hộ gia đình khảo sát gồm có chăn nuôi, trồng trọt, buôn bán..., và chủ yếu là chăn nuôi. Chăn nuôi là một ngành đang phát triển mạnh mẽ và tự phát ở nhiều hộ gia đình, tạo ra một nguồn thu nhập ổn định cho các hộ gia đình. Theo kết quả khảo sát, chăn nuôi chiếm tỷ lệ lớn nhất với $41,11 \%$ so với buôn bán và trồng trọt, bên cạnh đó thì trồng trọt và buôn bán cũng là nguồn thu nhập 
chính cho một số hộ gia đình khác, với tỷ lệ trồng trọt chiếm 24,45\% và tỷ lệ buôn bán chiếm $14,44 \%$. Với một số hộ gia đình có diện tích đất rộng, thì vừa chăn nuôi kết hợp với trồng trọt, giúp cho kinh tế phát triển mạnh mẽ hơn.

Vật nuôi của các hộ gồm có: bò, heo và gia cầm. Trong 90 hộ chăn nuôi được khảo sát, có đến 60 hộ chăn nuôi heo chiếm $66,67 \%, 19$ hộ nuôi gia cầm chiếm $21,11 \%$ và 11 hộ chăn nuôi bò chiếm $12,22 \%$.

Chăn nuôi quy mô từ 10 đến 50 con chiếm tỷ lệ cao nhất chiếm 53,33\%; quy mô nhỏ hơn 10 con chiếm 28,88\%; quy mô chăn nuôi trên 50 con chiếm tỷ lẹ̣ $17,79 \%$ so với tổng đàn theo hệ thống chăn nuôi hộ gia đình. Theo kết quả khảo sát và tổng hợp, quy mô chăn nuôi trên 10 con tập trung chủ yếu ở các hộ chăn nuôi heo, chiếm 52/90 hộ khảo sát; những hộ chăn nuôi với quy mô nhỏ hơn 10 con đối với vật nuôi là bò, gia cầm chiếm đa số.

Bảng 3. Bảng điều tra về quy mô chăn nuôi

\begin{tabular}{llccc}
\hline \multirow{2}{*}{ STT } & \multirow{2}{*}{ Vật nuôi } & \multicolumn{3}{c}{ Số lượng } \\
\cline { 3 - 5 } & Heo & Dưới 10 con & $10-50$ con & Trên 50 con \\
\hline 1 & Trâu bò & 8 & 42 & 10 \\
\hline 2 & Gia cầm & 8 & 1 & 0 \\
\hline 3 & Tồng cộng & 26 & 4 & 7 \\
\hline & & & 47 & 17 \\
\hline
\end{tabular}

Thời gian chăn nuôi được dùng để đánh giá mức độ ổn định của ngành, kết quả khảo sát thời gian tham gia chăn nuôi của các hộ khảo sát cho thấy đa số các hộ chăn nuôi đều chăn nuôi từ 2 năm trở lên, số hộ mới bắt đầu chăn nuôi với thời gian dưới 2 năm chiếm tỷ lệ thấp.

Bảng 4. Bảng điều tra thời gian chăn nuôi

\begin{tabular}{clcc}
\hline STT & \multicolumn{1}{c}{ Thời gian chăn nuôi (năm) } & Số phiếu & Tỷ lệ (\%) \\
\hline 1 & Dưới 2 năm & 6 & 6,67 \\
\hline 2 & Từ 2 đến 5 năm & 23 & 25,56 \\
\hline 3 & Từ 5 đến 10 năm & 35 & 38,89 \\
\hline 4 & Trên 10 năm & 26 & 28,88 \\
\hline \multicolumn{2}{c}{ Tổng cộng } & 90 & 100 \\
\hline
\end{tabular}

Mục đích của các hộ chăn nuôi gia súc, gia cầm đa số là để bán thịt chiếm $57,78 \%$, bán con giống chiếm 23,33\%, mục đích còn lại là lấy trứng.

Về khoảng cách từ chuồng nuôi và hố chứa chất thải đến nguồn: Các hộ chăn nuôi xây dựng khoảng cách từ chuồng nuôi đến nhà ở khoảng $5 \mathrm{~m}-20 \mathrm{~m}$ chiếm $65,55 \%$, khoảng cách này là phù hợp để giảm mùi đến nhà ở của các hộ dân, $11,11 \%$ số hộ có chuồng nuôi đến nhà ở dưới $5 \mathrm{~m}$, khi khảo sát thì cho thấy những hộ này có diện tích đất nhỏ, tận dụng chăn nuôi nên cách nhà không xa. Hố chứa chất thải đến nguồn nước giếng $5 \mathrm{~m}-20 \mathrm{~m}$ chiếm $50 \%$, nhỏ hơn $5 \mathrm{~m}$ chiếm $44,44 \%$, rất ít hộ xây dựng hố chứa chất thải đến giếng cách xa hơn $20 \mathrm{~m}$. Điều này sẽ làm ô nhiễm nguồn nước giếng của hộ chăn nuôi.

\subsubsection{Hiện trạng quản lý chất thải chăn nuôi}

Bảng 5. Phương thức vệ sinh chuồng nuôi

\begin{tabular}{|c|c|c|c|c|c|c|}
\hline \multirow{3}{*}{$\begin{array}{l}\text { Phương thức vệ sinh } \\
\text { Rửa chuồng }\end{array}$} & \multicolumn{6}{|c|}{ Quy mô chăn nuôi (con) } \\
\hline & \multicolumn{2}{|c|}{ Dưới 10 con } & \multicolumn{2}{|c|}{$10-50$ con } & \multicolumn{2}{|c|}{ Trên 50 con } \\
\hline & Số hộ & Tỉ lệ & Số hộ & Tỉ lệ & Số hộ & Tỉ lệ \\
\hline 1 lần/ngày & 20 & $76,92 \%$ & 31 & $64,58 \%$ & 7 & $43,75 \%$ \\
\hline Trên 1 lần/ngày & 0 & $0 \%$ & 15 & $31,25 \%$ & 7 & $43,75 \%$ \\
\hline 1 lần/nhiều ngày & 6 & $23,08 \%$ & 2 & $4,17 \%$ & 2 & $12,5 \%$ \\
\hline \multicolumn{7}{|l|}{ Dọn phân } \\
\hline Hốt phân- rửa chuồng & 6 & $23,08 \%$ & 29 & $60,42 \%$ & 10 & $62,5 \%$ \\
\hline Rửa chuồng + xịt phân & 3 & $11,54 \%$ & 13 & $27,08 \%$ & 0 & $0 \%$ \\
\hline Hốt phân - không rửa & 17 & $65,38 \%$ & 6 & $12,5 \%$ & 6 & $37,5 \%$ \\
\hline
\end{tabular}


Phương thức vệ sinh chuồng nuôi cũng như phương thức xử lý chất thải từ chăn nuôi quyết định chất lượng môi trường chăn nuôi và xung quanh.

Kết quả khảo sát phương thức vệ sinh chuồng nuôi được thể hiện ở bảng 5 theo quy mô chăn nuôi: Dưới 10 con, 10 - 50 con, Trên 50 con đối với các loại vật nuôi là trâu bò, heo và gia cầm.

Xét theo quy mô chăn nuôi, hầu hết các hộ đều ít nhất rửa chuồng 1 lần/ngày, với quy mô Dưới 10 con đa phần các hộ chăn nuôi rửa chuồng 1 lần/ ngày, có $23,08 \%$ số hộ nhiều ngày mới rửa chuồng. Với quy mô $10-50$ con, Trên 50 con đa phần các hộ chăn nuôi rửa chuồng nhiều lần trong ngày với tỷ lệ $31,25 \%$ $43,75 \%$. Các hộ chăn nuôi vài ngày mới rửa chuồng chỉ xuất hiện ở quy mô Dưới 10 con với tỷ lệ $23,08 \%$. Phương thức thu gom phân cũng khác nhau đối với mỗi hộ chăn nuôi, đa số các hộ hốt phân trước và rửa chuồng sau. Đối với những hộ chăn nuôi với số lượng lớn từ 50 con trở lên thì phương thức hốt phân và rửa chuồng chiếm $62,5 \%$, phân thu gom được dùng để bón cây hoặc bán. Còn những hộ chăn nuôi số lượng ít thường là dội luôn phân khi tắm heo, phương thức này sử dụng nhiều nước để rửa chuồng sẽ làm tăng khối lượng nước thải, gây tốn kém cho việc xử lý nước thải.

Theo khảo sát có 49 hộ chăn nuôi không xây dựng hệ thống mương dẫn, còn lại 41 hộ có xây dựng hệ thống mương dẫn nhưng chủ yếu mang tính tạm bợ.
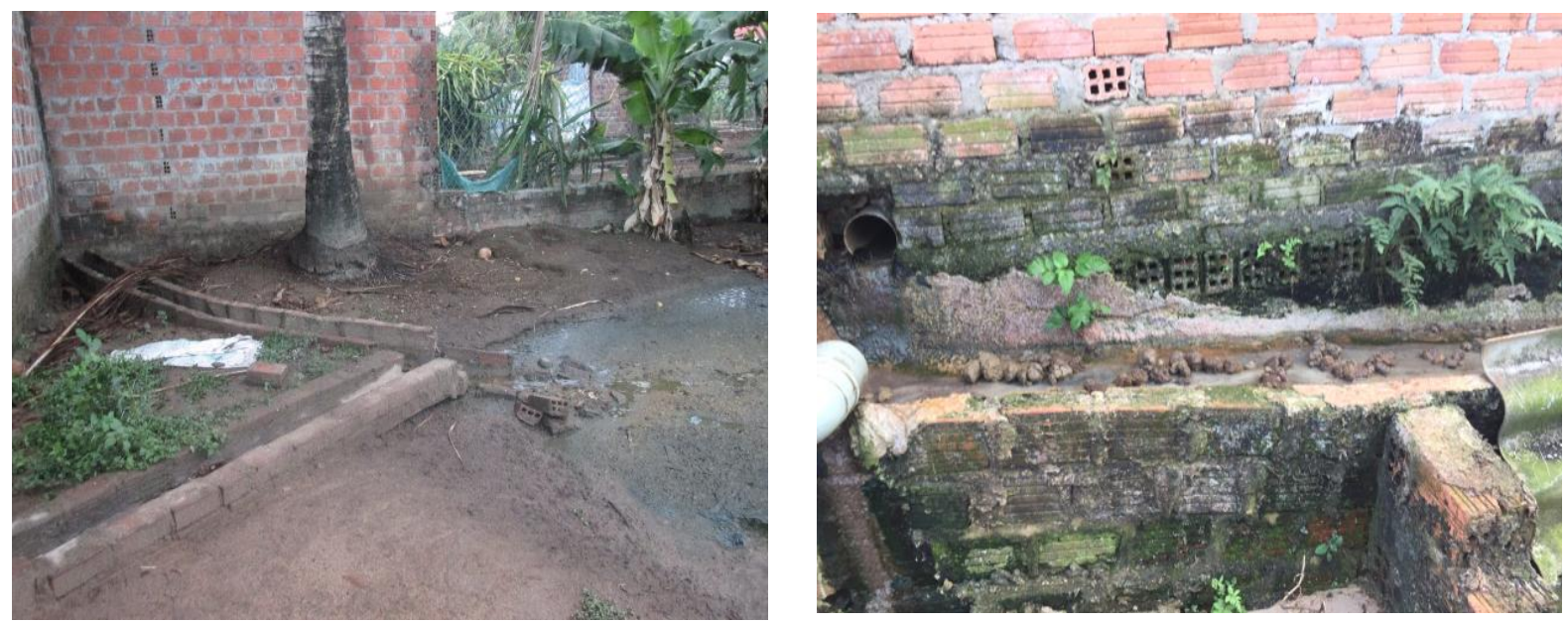

Hình 2. Mương dẫn chất thải chăn nuôi

Trong 41 hộ khảo sát có mương dẫn chất thải chăn nuôi có 22 hộ có mương dẫn chất thải hở như hình 2, mương dẫn hở được xây bằng xi măng, vì để dễ xử lý nếu chất thải bị ứ đọng, nhưng mà với cách này thì sẽ làm bốc mùi hôi, làm ảnh hưởng đến sức khỏe người chăn nuôi và môi trường xung quanh. Còn lại 19 hộ chăn nuôi có mương dẫn chất thải kín được xây dựng bằng ống nhựa $\varnothing 140$ và được lắp đặt âm kín dưới đất để dẫn chất thải trực tiếp xuống bể chứa. Điểu này cho thấy đa phần những hộ chăn nuôi chưa có đầu tư, quan tâm đến môi trường cho vật nuôi cũng như môi trường xung quanh gây ảnh hưởng đến môi trường.

Hệ thống xử lý chất thải chăn nuôi trên địa bàn có khoảng 54,45\% hộ chăn nuôi không có hệ thống lưu trữ, tức là phân tươi, nước tiểu và nước tắm dội chuồng thải trực tiếp ra đất tập trung hầu hết ở những hộ chăn nuôi có số lượng dưới 10 con và một số hộ chăn nuôi có số lượng từ 10 con đến 50 con. Hộ chăn nuôi có bể chứa chất thải chiếm $42,22 \%$, những bể này được phân bố theo quy mô chăn nuôi. Trong số những hộ có bể chứa chất thải này chỉ có $40 \%$ là bể chứa có nắp đậy. Đa số những hộ chăn nuôi xây dựng bể chứa chất thải không có nắp đậy chiếm tỷ lệ $60 \%$, gây ô nhiễm môi trường.

\subsubsection{Hiện trạng xử lý nuớc thải}

Nước thải trong chăn nuôi bao gồm nước tiểu, nước vệ sinh chuồng trại, tắm gia súc hay phân được dội chung khi rửa chuồng.[4] Lượng nước này có giá trị cho trồng trọt, cung cấp dinh dưỡng cho cây trồng nểu như sử dụng hợp lý. Ngược lại, đó là nguồn gây ô nhiễm môi trường nước, không khí, đất. Đặc biệt gây nên hiện tượng phú dưỡng hóa nguồn nước, làm mất cân bằng hệ sinh thái. Chất thải do hoạt động chăn nuôi chứa một lượng lớn các chất hữu cơ dễ bị phân hủy sinh học, các hợp chất chứa $\mathrm{N}, \mathrm{P}, \mathrm{K}$ hay vi sinh 
vật gây bệnh. Chúng sẽ lan truyền trong môi trường và ảnh hưởng đến môi trường nước, không khí, đất nếu không xử lý triệt để trước khi thải ra nguồn tiếp nhận.

Hiện nay, tại Thành phố Pleiku phương thức xử lý chủ yếu là dùng làm phân bón cho cây trồng, làm thức ăn cho cá, đối với nước thải thải ra ngoài chưa qua xử lý nên nồng độ chất ô nhiễm trong nước thải cao gây ô nhiê̂m đến môi trường xung quanh, đặc biệt là ô nhiễm nguồn nước mặt và nước ngầm.

Bảng 6. Hiện trạng xử lý nước thải

\begin{tabular}{lccc}
\hline \multirow{2}{*}{ Nguồn tiếp nhận } & \multicolumn{3}{c}{ Quy mô chăn nuôi (con) } \\
\cline { 2 - 4 } & Dưới 10 con & $\mathbf{1 0 - 5 0}$ con & Trên 50 con \\
\hline Mương nước & $11,54 \%$ & $18,75 \%$ & $6,25 \%$ \\
\hline Thải ra đất & $65,38 \%$ & $18,75 \%$ & $37,5 \%$ \\
\hline Hố ga & $23,08 \%$ & $62,5 \%$ & $56,25 \%$ \\
\hline
\end{tabular}

Theo Bảng 6 cho thấy nước thải chăn nuôi chủ yếu thải trực tiếp ra đất, ra mương thoát nước thải sinh hoạt chung của Thành phố và hố ga. Nguyên nhân chủ yếu các hộ không có vốn đầu tư. Một số khác do không có sự quan tâm, nhắc nhở, hỗ trợ từ chính quyền địa phương.

Xử lý chất thải bẳng biogas vừa tận dụng lượng khí sinh ra trong quá trình phân hủy kỵ khí chất hữu cơ làm khí đốt, vừa xử lý được chất thải. Để thực hiện được công việc này người chăn nuôi cần phải có kinh phí, mặt bằng xây dựng và hiểu biết về biogas. Trong thực tể tại Thành phố Pleiku biogas ứng dụng rất ít, mặc dù đây là phương pháp được ứng dụng rộng rãi trên thế giới.

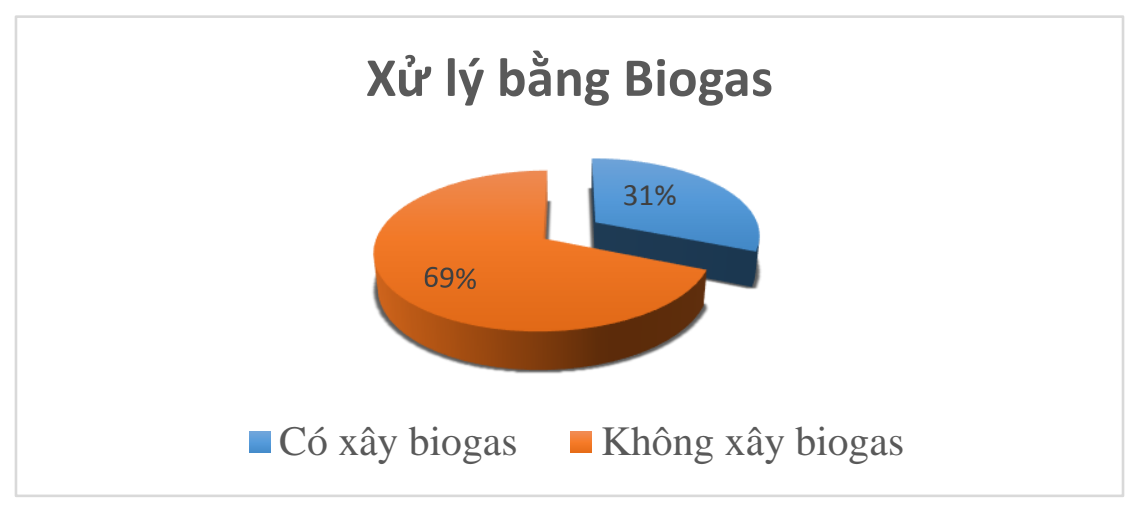

Hình 3. Tỷ lệ sử dụng biogas trong xử lý chất thải

Theo kết quả điều tra, cho thấy tỷ lệ các hộ chăn nuôi có xây dựng biogas để giảm thiểu nồng độ chất ô nhiễm trước khi thải ra nguồn tiếp nhận sản phẩm quá trình này là $31 \%$ tổng số hộ chăn nuôi. Trong đó, tập trung chủ yếu là các hộ chăn nuôi quy mô trên 50 con và các hộ chăn nuôi quy mô từ $10-50$ con, hầu như các hộ chăn nuôi quy mô dưới 10 con không xây dựng biogas.

\section{2 Đánh giá mức độ ô nhiễm môi trường nước do chất thải chăn nuôi tại Tp Pleiku}

\subsubsection{Kết quả phân tích chất lượng nước ngầm}

Tại Thành phố Pleiku, nước sử dụng trong chăn nuôi hầu như lấy từ nước giếng. Hiện nay nhiều hộ chăn nuôi không xây dựng hệ thống mương dẫn, hố chứa chất thải bằng xi măng hay sử dụng lớp vật liệu chống thấm, do đó chất thải dễ dàng thấm qua đất, ảnh hưởng đến chất lượng nước ngầm. Tiến hành lấy mẫu nước ngầm tại giếng đào của các hộ dân nằm trong khu vực chăn nuôi, kết quả phân tích cho thấy kết quả phân tích như Bảng 6.

Chất lượng nước ngầm của 03 mẫu đại diện được lấy mẫu 02 lần vào mùa nắng và mùa mưa có giá trị pH biến động trong khoảng 6,59 - 7,25. Giá trị pH đạt tiêu chuẩn cho nước tưới tiêu và nước sinh hoạt, các chỉ tiêu đều ở mức thấp. Tuy nhiên, nguồn nước ngầm của khu vực nghiên cứu bị ô nhiễm bởi E.Coli, nguyên nhân chủ yếu từ chất thải của hoạt động chăn nuôi. 

DO HOẠT ĐỘNG CHĂN NUÔI TẠI THÀNH PHỐ PLEIKU TỈNH GIA LAI

Bảng 7. Kết quả phân tích các chỉ tiêu trong nước ngầm

\begin{tabular}{|c|c|c|c|c|c|}
\hline \multirow{2}{*}{ Ngày lấy mẫu } & \multirow{2}{*}{ Ký hiệu mẫu } & \multirow{2}{*}{ pH } & COD & $\mathrm{NO}_{3}^{-}$ & \multirow{2}{*}{ E.Coli } \\
\hline & & & $\mathrm{mg} / \mathrm{l}$ & $(\mathrm{mg} / \mathrm{l})$ & \\
\hline \multirow{3}{*}{$21 / 03 / 2017$} & $\mathrm{~N} 1$ & 6,9 & 2,02 & 2,10 & 15 \\
\hline & N2 & 7,18 & 1,50 & 2,19 & 20 \\
\hline & $\mathrm{N} 3$ & 7,25 & 1,85 & 7,45 & 15 \\
\hline \multirow{3}{*}{$17 / 07 / 2017$} & N1 & 6,85 & 1,36 & 1,69 & 12 \\
\hline & $\mathrm{N} 2$ & 6,59 & 1,02 & 1,63 & 15 \\
\hline & $\mathrm{N} 3$ & 6,67 & 0,968 & 5,14 & 9 \\
\hline \multicolumn{2}{|c|}{ QCVN09:2015/BTNMT } & $5,5-8,5$ & 4 & 15 & KPH \\
\hline
\end{tabular}

3.2.2 Kết quả phân tích chất luọng nước mặt

Bảng 8. Kết quả phân tích các chỉ tiêu trong nước mặt

\begin{tabular}{|c|c|c|c|c|c|c|c|c|}
\hline \multirow{2}{*}{ Ngày lấy mẫu } & \multirow{2}{*}{$\begin{array}{c}\text { Ký } \\
\text { hiệu } \\
\text { mẫu }\end{array}$} & \multirow{2}{*}{ pH } & COD & BOD5 & TSS & $\mathrm{NO}_{3}{ }^{-}$ & $\mathrm{PO}_{4}{ }^{3-}$ & Coliform \\
\hline & & & $(\mathrm{mg} / \mathrm{l})$ & $(\mathrm{mg} / \mathrm{l})$ & $(\mathrm{mg} / \mathrm{l})$ & $(\mathrm{mg} / \mathrm{l})$ & $(\mathrm{mg} / \mathrm{l})$ & \\
\hline \multirow{3}{*}{$21 / 03 / 2017$} & M1 & 7,24 & 15,6 & 10,3 & 80,7 & 6,33 & 0,162 & 1.100 \\
\hline & M2 & 6,92 & 9,46 & 6,82 & $\mathbf{5 0 , 4}$ & 3,22 & 0,255 & 2.700 \\
\hline & M3 & 6,61 & 28,5 & 11,8 & 160 & 6,36 & 0,146 & 2.500 \\
\hline \multirow{3}{*}{$17 / 07 / 2017$} & M1 & 6,84 & 14 & 9,08 & 100 & 6,2 & 1,23 & 1.500 \\
\hline & M2 & 6,90 & 6,52 & 3,26 & 120 & 3,14 & 0,26 & 2.100 \\
\hline & M3 & 7,32 & 28,5 & 6,72 & 185 & 2,13 & 0,124 & 2.500 \\
\hline \multicolumn{2}{|c|}{ QCVN08:2015/BTNMT(B1) } & $5,5-9,0$ & 30 & 15 & 50 & 10 & 0,3 & 7500 \\
\hline
\end{tabular}

Mức độ ô nhiễm nước mặt phụ thuộc vào khối lượng chất thải, khả năng tự làm sạch của nguồn tiếp nhận, lưu lượng nước pha loãng, tác động các nguồn gây ô nhiễm. Kết quả khảo sát ảnh hưởng của chất thải chăn nuôi đến nguồn nước mặt được lấy 3 mẫu đại diện có các chỉ tiêu về $\mathrm{pH}, \mathrm{COD}, \mathrm{BOD}_{5}, \mathrm{NO}_{3}$, $\mathrm{PO}_{4}{ }^{3-}$, Coliform đạt QCVN 08:2015/BTNMT, chỉ tiêu nồng độ TSS vượt QCVN 08:2015/BTNMT gấp 1,008 đến 3,7 lần. So sánh kết quả phân tích của 3 phường cho thấy nồng độ TSS phường Iakring là cao nhất.

\subsubsection{Kết quả phân tích chất lương nước thải chăn nuôi}

Bảng 9. Kết quả phân tích các chỉ tiêu trong nước thải chăn nuôi

\begin{tabular}{cccccccr}
\hline \multirow{2}{*}{ Ngày lấy mẫu } & $\begin{array}{l}\text { Ký hiệu } \\
\text { mẫu }\end{array}$ & $\mathbf{p H}$ & COD & BOD $_{5}$ & TSS & Tổng N & Coliform \\
\cline { 3 - 8 } $21 / 03 / 2017$ & $\mathrm{NT} 1$ & 6,53 & $\mathbf{2 . 1 5 0}$ & $\mathbf{1 . 5 5 0}$ & $\mathbf{6 . 6 3 0}$ & $\mathbf{1 5 4}$ & $\mathbf{2 5 . 0 0 0}$ \\
\cline { 2 - 8 } & $\mathrm{NT} 2$ & 5,94 & $\mathbf{5 2 0}$ & $\mathbf{4 3 2}$ & $\mathbf{7 5 0}$ & 78,5 & $\mathbf{1 5 . 0 0 0}$ \\
\hline \multirow{2}{*}{$17 / 07 / 2017$} & $\mathrm{NT} 1$ & 6,18 & $\mathbf{2 . 8 4 0}$ & $\mathbf{2 . 0 1 5}$ & $\mathbf{5 . 2 7 0}$ & 126 & $\mathbf{5 0 . 0 0 0}$ \\
\cline { 2 - 8 } & $\mathrm{NT} 2$ & 6,52 & $\mathbf{4 6 8}$ & $\mathbf{3 5 2}$ & $\mathbf{8 0 0}$ & 62,8 & $\mathbf{2 2 . 0 0 0}$ \\
\hline \multirow{2}{*}{ QCVN 62-MT: 2016/BTNMT } & $5,5-9$ & 300 & 100 & 150 & 150 & 5.000
\end{tabular}

(B)

Qua kết quả phân tích chất lượng nước thải chăn nuôi heo cho thấy thông số ô nhiễm của nước thải chăn nuôi heo nước thải cũng có các chỉ tiêu vượt tiêu chuẩn thải ra ngoài theo QCVN 62MT:2016/BTNMT cột $B$. Nước thải từ các hộ chăn nuôi phần lớn thải trực tiếp ra mương nước, đất mà không qua xử lý cho nên đã ảnh hưởng nghiêm trọng đến chất lượng môi trường xung quanh, đặc biệt là 
môi trường nước. Đồng thời dựa vào kết quả phân tích 2 mẫu nước thải cho thấy nước thải chăn nuôi hốt phân trước rửa chuồng sau có các chỉ tiêu thấp hơn so với nước thải rửa chuồng đồng thời xịt và hốt phân sau, tuy nhiên các chỉ tiêu này đã cũng vượt quy chuẩn cho phép QCVN 62-MT:2016/BTNMT cột $B$. Như vậy, để giảm nồng độ chất ô nhiễm thải ra môi trường nước, tạm thời chưa có hệ thống xử lý nước thải, cần thu gom phân trước để xử lý riêng, sau đó rửa chuồng và tắm gia súc.

\subsection{4 Đánh giá chung}

Qua quá trình khảo sát điều tra về hiện trạng chất thải chăn nuôi tại Thành phố Pleiku, nhận thấy hiện trạng về môi trường như sau:

Nguồn phát sinh chất thải ở hoạt động chăn nuôi chủ yếu là phân và nước thải. Một số hộ có số lượng heo nhiều làm sản sinh ra nhiều chất thải nhưng lại chưa có biện pháp xử lý chất thải hợp lý. Việc xây dựng trang trại và quy trình nuôi chưa đạt yêu cầu.

Các hệ thống mương dẫn chất thải và hố đựng chất thải chưa được xây phù hợp như mương dẫn hở và hố chứa thì không có nắp đậy gây ảnh hưởng tưới sức khỏe và môi trường.

Mẫu nước được lấy một cách ngẫu nhiên tại các địa điểm lấy mẫu đã cho thấy nguồn nước mặt hiện tại đã có bị ô nhiễm $\mathrm{PO}_{4}{ }^{3-}$ và TSS, các mẫu nước ngầm có bị nhiễm E.Coli, điều này chứng tỏ thực trạng $\mathrm{o}$ nhiễm nước ngầm do hoạt động chăn nuôi heo là một vấn đề cần được lưu tâm trong thời gian tới. Về nước thải thì các thông số đều có giá trị vượt ngưỡng nhiều lần so với giá trị tối đa cho phép, thể hiện được tình trạng nước thải ở đây bị ô nhiễm nặng.

Hầu như các hộ gia đình ở đây chưa có biện pháp xử lý chất thải hiệu quả và đúng cách, những biện pháp xử lý vẫn còn những hạn chế nhất định, nguồn chất thải lớn, chưa được xử lý triệt để trước khi xả vào nguồn nước tiếp nhận, một số hộ gia đình thì thải thẳng trực tiếp ra bên ngoài môi trường làm ảnh hưởng đển môi trường và sức khỏe mọi người xung quanh.

Các chủ hộ chăn nuôi heo chưa có ý thức bảo vệ môi trường, việc tuân thủ pháp luật về bảo vệ môi trường chưa cao. Việc ủ phân để làm phân bón hoặc bón trực tiếp cho cây trồng gây ô nhiễm cho môi trường xung quanh .

\section{3 Đề xuất các giải pháp kỹ thuật và quản lý nhằm giảm thiểu ô nhiễm môi trường nước cho ngành chăn nuôi}

Trong điều kiện hiện nay sự kết hợp giữa phát triển kinh tế và bảo vệ môi trường, để thực hiện tốt công tác phòng chống và giảm thiểu ô nhiễm môi trường nước do chăn nuôi, đề tài đã đề xuất một số giải pháp sau:

\subsubsection{Giải pháp kỹ thuật}

Xây dựng chuồng trại nơi thoáng mát, đảm bảo có ánh nắng buổi sáng chiếu vào buổi sáng để có thể giúp chuồng khô thoáng và đỡ mùi. Đảm bảo chuồng trại cách xa nhà ở và nguồn nước sử dụng và đặt ở cuối hướng gió chính để tránh phát tán mùi hôi đến các hộ dân cư xung quanh. Cần tư vấn và khuyến khích người dân áp dụng các khoa học kỹ thuật tiên tiến trong việc chăn nuôi và xử lý chất thải.

Thu gom, lưu trữ, vận chuyển chất thải:

Thu gom: Phân và nước tiểu gia súc sau khi động vật thải ra được thu gom khỏi chuồng càng sớm càng tốt. Phải thu phân và các chất thải rắn khác trước khi dội chuồng, nhằm hạn chế nồng độ chất ô nhiễm có trong nước thải.

Luu trũ: Tránh lưu trữ phân lâu và nơi lưu trữ phân cách biệt với chuồng trại và xa nhà ở, xa nguồn nước để không ảnh hưởng đến sức khỏe gia súc, con người và phải đậy kín.

Vận chuyển chất thải chăn nuôi: Vận chuyển tránh rơi vãi phân rắn, dùng thùng chứa, có nắp đậy kín, không rò rĩ hoặc chảy tràn phân lỏng và nước trên đường vận chuyển.

Xử lý chất thải chăn nuôi: Chất thải bao gồm phân và nước thải, do tính chất khác nhau nên hình thành hai nhóm các phương pháp xử lý phân và nước thải chăn nuôi khác nhau.

Xủ lý phân bằng cách ủ phân: Ủ phân ở nơi có mái che tránh mưa, nắng, cần có mương dẫn nước rò rĩ từ hố ủ đến nơi xử lý nước thải, không cho chất thải tiếp xúc trực tiếp với môi trường đất sẽ ảnh hưởng đến nguồn nước ngầm và đất. Dựa vào thể tích thải phân hàng ngày của từng loại gia súc, gia cầm theo tác giả Ngô Kế Sương và Nguyễn Lân Dũng (1997) [3] thì thể tích hố ủ phân tối thiểu được tính cho $500 \mathrm{~kg}$ vật nuôi được nêu trong bảng sau: 
DO HOẠT ĐỘNG CHĂN NUÔI TẠI THÀNH PHỐ PLEIKU TỈNH GIA LAI

Bảng 10. Thể tích hố ủ phân cho 500 kg vật nuôi theo phương pháp ủ

\begin{tabular}{lcccc}
\hline \multirow{2}{*}{ Vật nuôi } & \multirow{2}{*}{ Thể tích phân $\left(\mathbf{m}^{\mathbf{3}}\right)$} & \multicolumn{3}{c}{ Thể tích hố ủ phân $\left.\mathbf{( m}^{\mathbf{3}}\right)$} \\
\cline { 3 - 5 } & 0,038 & Ủ nóng & U hỗn hợp & Ủ nguội \\
\hline Trâu, bò & 0,028 & $2,3-2,5$ & $3,0-3,5$ & 6,5 \\
\hline Heo & 0,028 & $1,7-2,0$ & $2,3-2,5$ & 4,8 \\
\hline Gà, vịt & $1,7-2,0$ & $2,3-2,5$ & 4,8 \\
\hline
\end{tabular}

Tuy nhiên, để đảm bảo an toàn khi xây dựng hố ủ, phải xây dựng hố có thể tích lớn hơn thể tích tính toán nhằm tránh quá tải, dẫn đến chất thải rơi vãi ra ngoài hoặc phân chưa hoai đã lấy ra để cho phân mới vào. Thông thường phải xây hố ủ hai ngăn để luân phiên và phải có hệ thống dẫn nước đến nơi xử lý.

Xử lý nước thải chăn nuôi:

Chất ô nhiễm trong nước thải chăn nuôi phụ thuộc vào phương thức thu gom chất thải. Nên áp dụng cách hốt phân trước rồi rửa chuồng sau, như vậy sẽ có thể tiết kiệm được nước và giảm được nguồn phát sinh nước thải.

Áp dụng phương pháp sinh học [2]: Đối với những hộ có diện tích rộng nên áp dụng xây hồ sinh học, vừa giúp xử lý nước thải vừa có thể nuôi thủy sản, hoặc dùng làm nước tưới cây trồng trọt và xử lý nước thải bằng cây thủy sinh như cây muỗi nước, cây bèo lục bình...

Khuyến khích các hộ gia đình xây dựng hệ thống Biogas xử lý nước thải

Ngoài ra, còn có thể hạn chế ô nhiễm bằng hình thức chăn nuôi mới như chăn nuôi trên nền đệm lót sinh thái với các vi sinh vật có ích.

\subsubsection{Giải pháp quản lý}

Việc xây dựng cơ cấu tổ chức quản lý môi trường tại cấp phường, tổ dân phố là một yếu tố quan trọng quyết định trong triển khai các hoạt động bảo vệ môi trường ở địa phương.

Đẩy mạnh thực hiện phát triển chăn nuôi gắn với phòng chống ô nhiễm môi trường tại địa phương. Tiến hành kiểm tra các cơ sở chăn nuôi gây ô nhiễm và đề xuất giải pháp giải quyết cơ bản ô nhiểm do chăn nuôi.

Khuyến khích các hộ chăn nuôi di dời chuồng trại ra xa khu dân cư.

Giám sát môi trường: Tiến hành đo đạc, giám sát chất lượng môi trường định kỳ để có thể phát hiện và xử lý kịp thời các vấn đề ô nhiễm môi trường phát sinh trong quá trình chăn nuôi.

Phối kết hợp quản lý của các cơ quan ban ngành để tư vấn kỹ thuật xử lý chất thải, hướng dẫn hộ chăn nuôi sử dụng chất thải chăn nuôi có hiệu quả và giải quyết các vấn đề ô nhiểm môi trường ở địa phương.

\subsubsection{Giáo dục môi truờng và nâng cao nhận thức của người dân}

Nội dung giáo dục môi trường nhằm làm cho người dân hiểu biết về những ảnh hưởng môi trường và sức khoẻ do chăn nuôi, trách nhiệm và sự tham gia của họ trong các hoạt động vệ sinh môi trường. Đội ngũ tuyên truyền chủ yếu tập trung ở cấp phường, tổ dân phố là hội phụ nữ và đoàn thanh niên.

Các công cụ tuyên truyền: In ấn, phát tờ rơi quảng cáo về hoạt động bảo vệ và cải thiện môi trường tại địa phương.

Cần tổ chức họp vào mỗi tháng để mọi người chia sẽ những kinh nghiệm đã đạt được và áp dụng tốt hơn vào chăn nuôi đạt hiệu quả kinh tế cao, hạn chế được nguồn chất thải.

\subsubsection{Hỗ trợ các cơ sở chăn nuôi về mặt kỹ thuật và tài chính để xây dựng các công trình xử lý chất thải chăn nuôi phù hợp}

Hướng dẫn quy cách xây dựng chuồng, trại hợp vệ sinh, hệ thống mương thoát, hố lắng nước thải, hệ thống xử lý chất thải chăn nuôi.

Phổ biến các quy trình quản lý - xử lý - sử dụng chất thải chăn nuôi, phân tích mức đầu tư - hiệu quả xử lý để các cơ sở chăn nuôi lựa chọn mô hình thích hợp cho cơ sở.

Hạn chế chăn nuôi trong điều kiện không có khả năng quản lý, xử lý chất thải chăn nuôi, đảm bảo vệ sinh cho người và gia súc.

\section{KẾT LUẬN}

Qua kết quả nghiên cứu cho thấy tại Thành phố Pleiku, các hộ chăn nuôi lựa chọn chăn nuôi heo chiếm tỷ lệ cao nhất $57,98 \%$ với quy mô từ 10 đến 50 con chiếm tỷ lệ $53,33 \%$, trong đó có $54,44 \%$ hộ chăn nuôi 
không xây dựng hệ thống mương dẫn, còn lại 45,56\% hộ có xây dựng hệ thống mương dẫn nhưng chủ yếu mang tính tạm bợ. Khoảng cách từ chuồng nuôi đến nhà ở và từ hố chứa chất thải đến nguồn nước còn gần. Chất thải chăn nuôi được $35,56 \%$ số hộ chăn nuôi thải trực tiếp ra môi trường đất mà không qua biện pháp xử lý làm ô nhiễm môi trường, đặc biệt là môi trường nước.

Kết quả phân tích chất lượng nước ngầm, nước mặt từ các khu vực gần trang trại chăn nuôi cho thấy có ô nhiễm E.Coli, $\mathrm{PO}_{4}{ }^{3-}$, gây ảnh hưởng đến môi trường đô thị. Kết quả phân tích chất lượng nước thải cao hơn rất nhiều lần so với quy định cho phép.

Đề tài cũng đã đề xuất các giải pháp nhằm giảm thiểu ô nhiễm môi trường nước do hoạt động chăn nuôi như giải pháp kỹ thuật xây dựng chuồng trại, thu gom, lưu trữ, vận chuyển, xử lý chất thải chăn nuôi; Giải pháp về quản lý từ cấp phường, tổ dân phố, xây dựng các chương trình hỗ trợ, giám sát ô nhiễm môi trường của các cơ quan chức năng, khuyến khích hộ chăn nuôi di dời chuồng trại xa khu dân cư; Giáo dục môi trường và nâng cao nhận thức của người dân, hỗ trợ các cơ sở chăn nuôi về mặt kỹ thuật và tài chính để xây dựng các công trình xử lý chất thải chăn nuôi phù hợp.

\section{LỜI CẢM ƠN}

Nghiên cứu này được hỗ trợ bởi kinh phí nghiên cứu khoa học của trường Đại học Nông Lâm Tp.Hồ Chí Minh cho đề tài cơ sở số CS_CB16_PHGL_10.

\section{TÀI LIỆ THAM KHẢO}

[1] Cục thống kê- niên giám thống kê tỉnh Gia Lai 2012, 2013, 2014, 2015, 2016.

[2] Lương Đức Phẩm (2009). Công nghệxử lý nước thải bằng biện pháp sinh học. NXB Giáo dục Việt Nam.

[3] Ngô Kế Sương và Nguyễn Lân Dũng, 1997. Sản xuất khí đốt (biogas) bằng kỹ thuật lên men kỵ khí. NXB Nông nghiệp.

[4] Nguyễn Thị Hoa Lý (1994), Nghiên cứu các chỉ tiêu ô nhiễm bẩn của chất thải chăn nuôi heo tập trung và áp dụng một số biện pháp xử lý, Luận án phó tiến sĩ Khoa học công nông nghiệp, Đại học Nông Lâm thành phố Hồ Chí Minh.

[5] Ủy ban nhân dân Thành phố Pleiku (2016). Báo cáo tình hình thực hiện kế hoạch phát triển kinh tế - xã hội năm 2015 và muc tiêu, nhiệm vu năm 2016.

Ngày nhận bài: 15/3/2018

Ngày chấp nhận đăng: 28/4/2018 